\title{
THE EFFECTS OF RILL EROSION ON UNPAVED FOREST ROAD
}

\author{
VAROL, T..$^{1 *}$-ERTUĞRUL, M. ${ }^{1}-$ ÖZel, H. B. ${ }^{1}-$ EMIR, T. ${ }^{1}-$ ÇETIN, M. ${ }^{2}$ \\ ${ }^{1}$ Department of Forest Engineering, Faculty of Forestry, Bartın University, Bartın, Turkey \\ (phone: +90-378-223-5171) \\ ${ }^{2}$ Department of Landscape Architecture, Faculty of Engineering and Architecture, Kastamonu \\ University, Kastamonu, Turkey \\ (phone: +90-360-280-2920) \\ *Corresponding author \\ e-mail: tvarol@bartin.edu.tr; phone: +90-378-223-5171
}

(Received $25^{\text {th }}$ Sep 2018; accepted $26^{\text {th }}$ Nov 2018)

\begin{abstract}
This research aims to investigate the degree of rill erosion and its relationship with the factors effective on rill volume on unpaved forest roads in Bartın Province in Turkey. For this purpose, measurements were made at 380 sample locations on different regions of the forest roads in Arit and Hasankadi sub-districts. The measurements were performed on 4 years old unpaved forest roads. Among the road surface (RS), road cut (RC), sidecast fill (SCF) and skid trail (ST) road sections, RS and ST ranked as the first two sections with the highest segment length. Segment length is characterized as the most effective field factor on erosion, which further increased the rill volume by the combined effect of increasing slope, in this research. According to the stepwise (forward-backward) regression analysis results, inclusion of both segment length and slope parameters in the RS, SCF and RC equations supports this finding. The correlation of all road sections (RS, SCF, RC, ST) with the segment length are 0.84, $0.63,0.75$ and 0.83 , respectively, and the correlation with the slope are $0.55,0.73,0.57$ and 0.64 , respectively. As a result of the slope-based categorization of the relationship between segment lengths and rill volume for the road sections, $\mathrm{R}^{2}$ values were found to increase up to 0.88 for RS, 0.78 for SCF, 0,94 for RC and 0.88 for ST. The rill volume at short and steep roads can be lower than the rill volume at long and low-slope roads. Therefore, we calculated the rill volumes per unit road segment area. As a result of application of equations based on shear stress and stream power sediment transport capacity theory, RMSE values with very low mean error were obtained. In further related studies, drainage areas in addition to segment lengths and slope should also be taken into account to determine the positive and negative effects in evaluation of rill erosion amounts. Also, similar studies should be performed on other basins having a larger number of unpaved forest roads as a means to extend the applicability of the obtained findings.
\end{abstract}

Keywords: soil loss, road erosion, sediment sources, hydrological constituents, unpaved road

\section{Introduction}

Unpaved forest roads cover a relatively tiny area of a basin, though they have a major effect on numerous hydrological and geomorphic processes in a given basin and they act as a primary sediment source, which make them an interesting subject for various research (Megahan, 1987; Luce and Wemple, 2001; Ramos-Scharron and MacDonald, 2005; Cao et al., 2011, 2014, 2015). The combined effect of soil compaction resulting in reduced infiltration capacity of road surface and the vehicleinduced increase in the sediment yield leads to an increase in surface runoff (Sidle et al., 1985; Ziegler et al., 2000; Croke and Mockler, 2001; Gucinsky et al., 2001; Dougherty et al., 2004; Xu et al., 2007; Eisenbies et al., 2007; Cao et al., 2011; McGroody et al., 2013). This formation occurs even to a greater extent than mass movements (Ketcheson et al., 1999). It has been reported in studies performed in various locations (Australia, China, England, Ghana, Kenya, Kuwait, Malaysia, New Zealand, Norway, Poland, The 
United States, Tunusia etc.) that, forestlands feature lower erosion whereas unpaved forest roads exhibit significantly higher erosion (Dunne, 1979; Reid and Dunne, 1984; Kumapley, 1987; Fahey and Coker, 1989; Burroughs et al.,1991; Froehlich, 1991; Douglas, 1993; Grayson et al., 1993; Froehlich and Walling, 1997; Fransen et al., 2001; Xu et al., 2009; Posthumus et al., 2011; Tommervik et al., 2012; Foster et al., 2012; AlAwadhi, 2013; Desprats et al., 2013; Leh et al., 2013). In this regard, evaluation of the sediment yield of unpaved forest roads gains an increasing importance.

As a result of the higher erosion rates on unpaved forest roads compared to openchannel flow areas or areas with heavy vegetation (such as agriculture and pasture areas), data specific to such areas have been used in estimation of road-induced sediment in the last fifty years (Ramos-Scharron and MacDonald, 2007; Croke et al., 1999). Particularly, conducting an effective land planning requires a good understanding of road-induced erosion and sediment production process. River monitoring, sediment determination methods and road erosion models are widely used to estimate the road-induced erosion. Silt fences, installed on road sites, provide useful information at coarse grained (such as sand and gravel) roads, but they do not provide precise information in determination of fine sediment yields (Ramos-Scharron and MacDonald, 2007). Besides their convenience, monitoring methods are more costly.

SEDMODL2 (Road Sediment Delivery Model), WARSEM (Washington Road Surface Erosion Model), CULSED, USLE (Universal Soil Loss Equation) and its modifications, and ROADMOD are the test based models; whereas WEPP (The Water Erosion Prediction Project) and KINEROS2 (Kinematic Runoff and Erosion Model) are physical models used in estimation of sediment yield (Dube et al., 2004; Cochrane et al., 2007; Elliot et al., 2009; Fu et al., 2010; Cao et al., 2011; Varol, 2015, 2016). Considering the statistical relationship between the observation-driven results derived from experimental models and dependent variables, the use of these models in diverse studies becomes a challenge due to their field-specific nature (Merritt et al., 2003). Physical models are mainly based on hydrological reactions and these models simulate infiltration and run-off routines. Case-based models, on the other hand, estimate the sediment yield produced as a result of a single rainfall or run-off event, thus simulating the erosion. Moreover, experimental models are continuous, whereas physical models are case-based models.

As reported in the studies performed on unpaved forest roads in Turkey; sediment yields vary between $0-2.715$ tons on gravel-surfaced road sections, and between 1.476 - 28.667 tons on asphalt roads. Spatial sediment yield varies between $0.0004 \mathrm{t} / \mathrm{m}^{2}$ and $0.0199 \mathrm{t} / \mathrm{m}^{2}$ on gravel surfaced grounds, and between $0.0051 \mathrm{t} / \mathrm{m} 2$ and $0.0636 \mathrm{t} / \mathrm{m}^{2}$ on asphalt roads (Akay et al., 2008). In addition to the afore-stated studies quantitative works on soil erosion characteristics of unpaved roads are also required (Xu et al., 2009; Varol, 2016). Investigation of erosion characteristics is particularly required for steep unpaved forest roads that receive large amounts of rain such as those in Karadeniz Region. GPS aided road surveys and GIS methodology have been commonly used in investigation of road-induced erosion characteristics as these are closely associated with road types and spatial variables. In this regard, the present research was conducted at Arıt and Hasankadı Sub-district Directorates of Bartın Forestry Directorate with a view to: (1) define the amount and spatial distribution of road erosion, (2) clarify the relationship between the road segments' erosion characteristics and the effective factors, and (3) propose equations that can be used in estimation of erosion. 


\section{Material and method}

\section{Study area}

The erosion estimation studies for unpaved forest roads were performed in Arit $\left(32^{\circ}\right.$ 24 ' $20^{\prime \prime}-32^{\circ} 44^{\prime} 50^{\prime \prime}$ east longitudes and $41^{\circ} 33^{\prime} 90^{\prime \prime}-41^{\circ} 45^{\prime} 70^{\prime \prime}$ north latitudes) and Hasankad $1\left(41^{\circ} 17^{\prime} 48^{\prime \prime}-41^{\circ} 22^{\prime} 35^{\prime \prime}\right.$ north latitudes and $32^{\circ} 16^{\prime} 48^{\prime \prime}-32^{\circ} 29^{\prime} 06^{\prime \prime}$ east longitudes) sub-district directorates of Bartın Forest Directorate in Turkey (Fig. 1). The region is dry and hot in summers (Csa) (Varol and Ertugrul, 2015) with a mean yearly temperature of $12.8{ }^{\circ} \mathrm{C}$, and annual precipitation is $1044.5 \mathrm{~mm}(1965-2017$ The total rainfall in 2017 in which the study was carried out was $1209.3 \mathrm{~mm}$ above the average of 1965-2017 period. In 2017, the highest monthly rainfall amounted to $242.7 \mathrm{~mm}$ in August. The sample unpaved forest road locations surrounded with forestlands in both sub-districts are located in basins with about $17.4(14.6+2.8) \mathrm{km}^{2}$ acreage and their altitudes above sea level vary between 750 and $1200 \mathrm{~m}$. Both road sections are in Kilimli formation and they are composed of Cretaceous aged bedrock sandstonecarbonate sand-stone. In the study area, agricultural and settlement areas in Arit subdistrict cover the largest area $\left(7.74 \mathrm{~km}^{2}\right)$ which are followed by fertile $\left(6.14 \mathrm{~km}^{2}\right)$ and rough $\left(0.7 \mathrm{~km}^{2}\right)$ forestlands and forest soil. Hasankad1 sub-district is completely composed of fertile forestlands $\left(2.87 \mathrm{~km}^{2}\right)$.

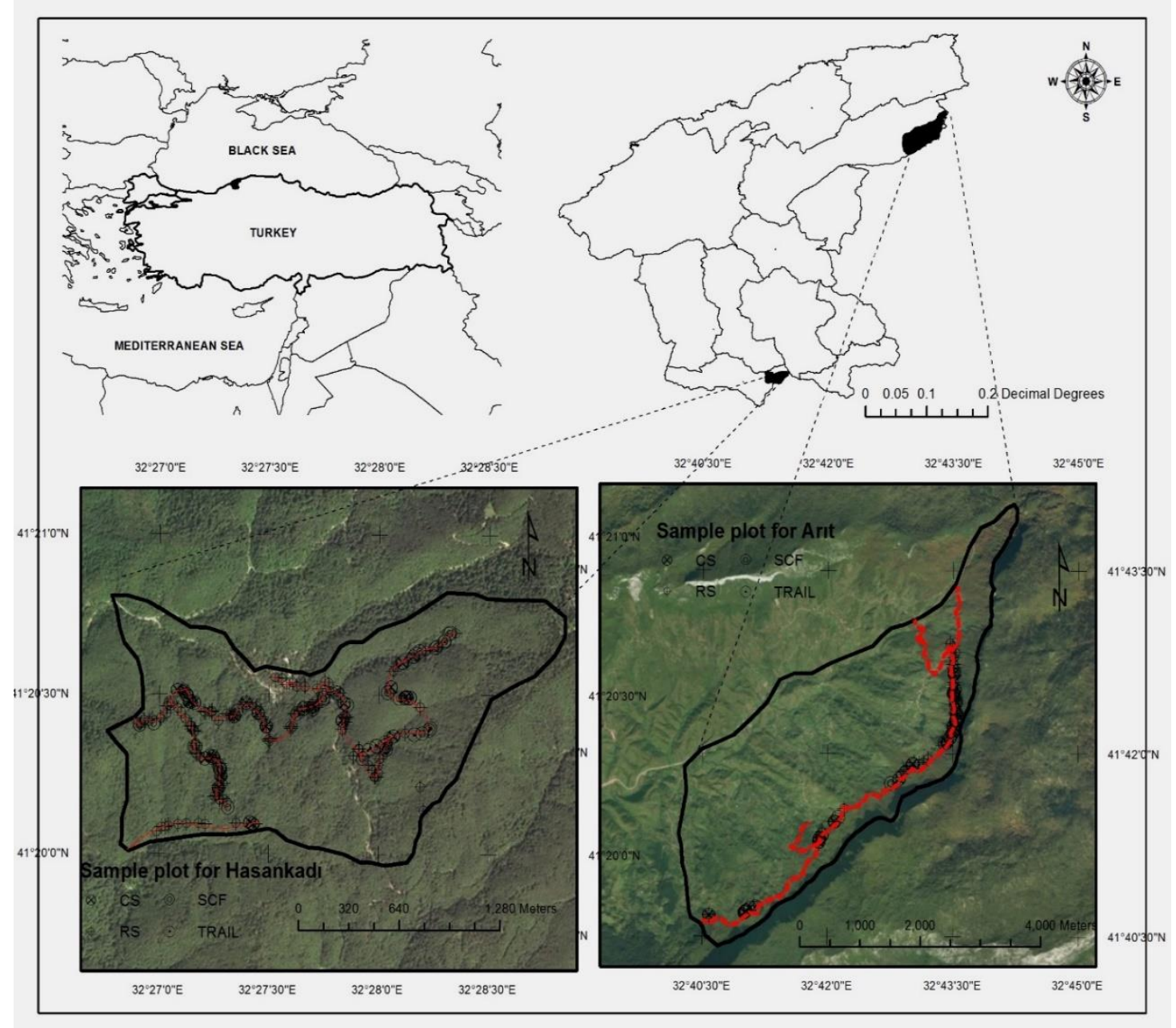

Figure 1. The location of study area 


\section{Road network}

A forest road consists of a series of hydrological constituents such as road surface (RS), road cut (RC) and sidecast fill (SCF) (Fig. 2). Road surface represents the unpaved surface of the road on which vehicles move, road cut represents the straightly or curvedly cut profile of the slope of the road, and sidecast fill defines the aggregates right under the road that forms during road construction. No vegetation is observed on the road cut sections that have an average height of 2-5 meters and the sidecast fill sections that have straight profiles. Segment lengths observed in the study area vary between 5.0-285.7 $\mathrm{m}$ for road cut segment, 3.5-477.3 $\mathrm{m}$ for road surface, 2.9-99.6 $\mathrm{m}$ for sidecast fill, and 2.2-102.4 $\mathrm{m}$ for skid trails.

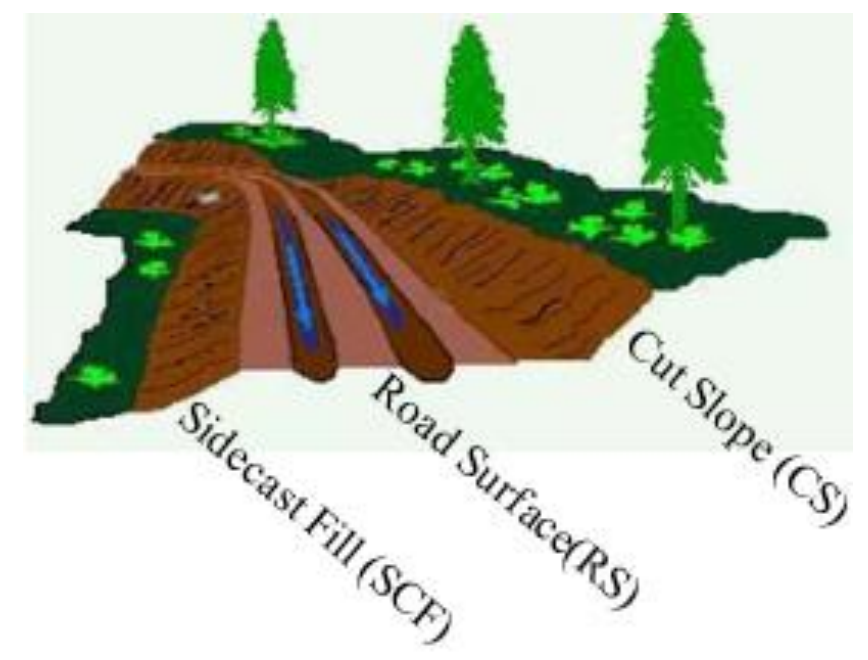

Figure 2. Components of a road (Elliot et al., 2009)

The total forest road length of Arit sub-district is $148610 \mathrm{~m}$, and that of Hasankad1 sub-district is $115700 \mathrm{~m}$. All forest roads in Arit sub-district are B-type secondary forest roads (The platform width is 3-5 m, ditch width is $0.50-1 \mathrm{~m}$, total width of 3.5-6 m, the minimum curve radius is $12 \mathrm{~m}$, maximum slope $12 \%$, which are generally unpaved roads. The annual amount of product to be transported on these roads is less than $25000 \mathrm{~m}^{3}$ ) and only $3 \%$ are paved forest roads. Those in Hasankad1 sub-district are also B-type secondary forest roads and 30\% are paved forest roads. Accordingly, the roads in both sub-districts are largely void of road pavement to bear the vehicle loads. These roads have been used for transportation purposes by local residents in addition to forestry and agricultural activities. These roads do not have any surface cover. Compacting is materialized by the vehicles used in agricultural and forestry activities. The newly constructed roads in the road network plan were manually digitized and involved in the network plan. The road surface, road cut and sidecast fill sections of the study area were constructed four years before 2017, skid trail sections were constructed ten years ago. In parallel to the increasing run-off followed by rainfall, surfaces of unpaved forest roads lead to increasing sediment transport. Sediment transport occurs at higher rates at rills that form on the road segments (RS, RC, SCF) (Fig. 3). Therefore, rill formations on each road segments have been subject to examination in this research. In general, a road segment is characterized with the road length between two nodes (Tanimoto, 1999; MacDonald et al., 2001). 


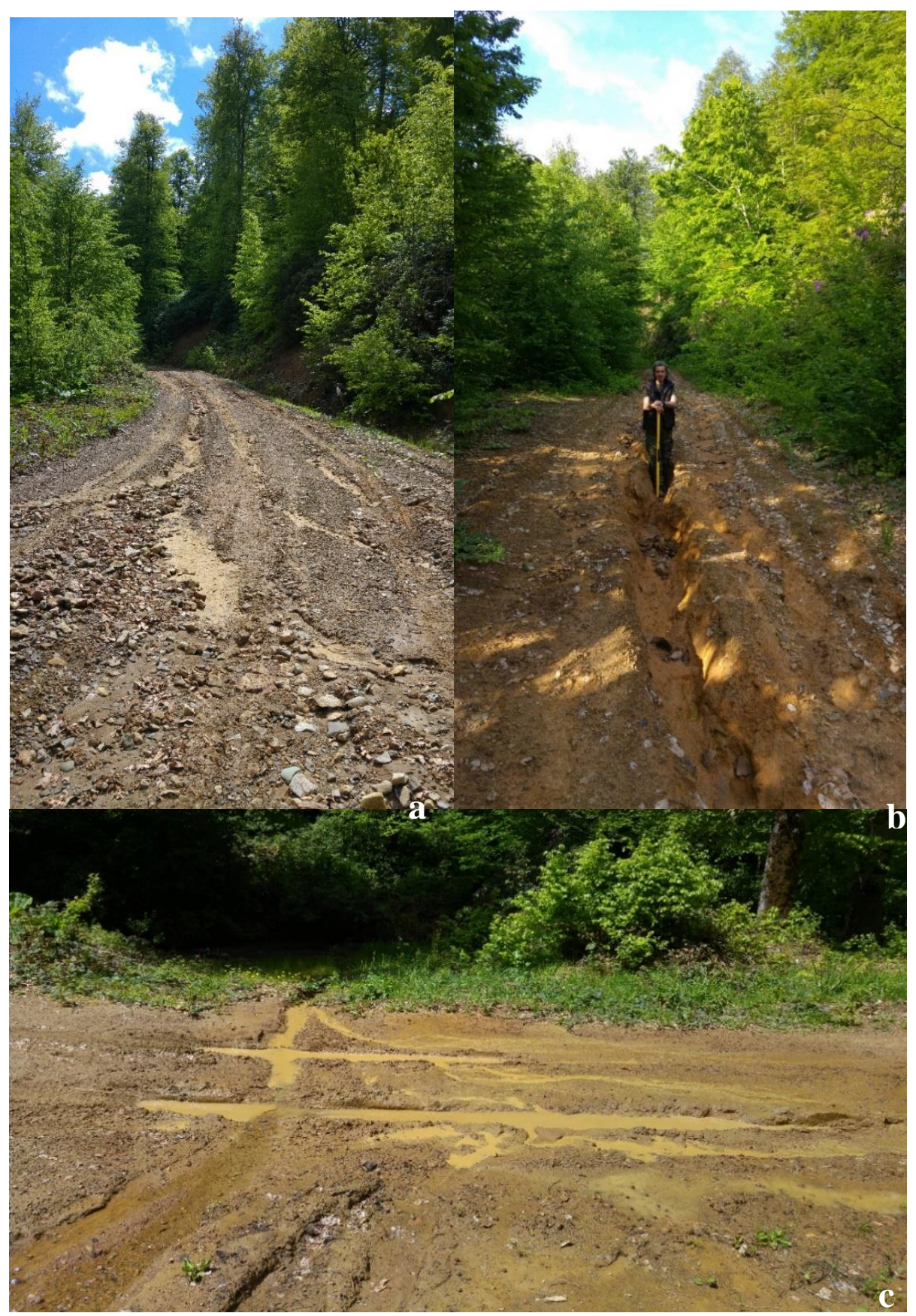

Figure 3. Unpaved road segment samples. a Sediment transport along the rills that form on the road segment. $\boldsymbol{b}$ Highly eroded road surface. $\boldsymbol{c}$ Erosion on the node where two road segments intersect

A road segment can be terminated by intersection of the node with another road or an artificial boundary, or it can start and end by a change in road characteristics (such as slope, exposure, etc.). A road segment can be defined as a section of the rode with an independent drainage area (Cao et al., 2014). During the road measurements, the start and end points of road segments in addition to the segment lengths and variations in slope were determined via GPS. The characteristics of the road network and road segments on which the measurements were performed are shown in Table 1. 
Table 1. Characteristics of the road network and road segments in the study area

\begin{tabular}{c|c|c|c|c|c|c|c}
\hline \multirow{2}{*}{$\begin{array}{c}\text { Road } \\
\text { type and } \\
\text { segments }\end{array}$} & \multicolumn{2}{|c|}{ Road network's characteristics } & \multicolumn{4}{c}{ Road segments' characteristics } \\
\cline { 2 - 7 } & $\begin{array}{c}\text { Total } \\
\text { length (km) }\end{array}$ & $\begin{array}{c}\text { Mean width } \\
(\mathbf{m})\end{array}$ & $\begin{array}{c}\text { Road density } \\
\left(\mathbf{k m} / \mathbf{k m}^{2}\right)\end{array}$ & Count & $\begin{array}{c}\text { Mean length } \\
(\mathbf{m})\end{array}$ & $\begin{array}{c}\text { Ratio of rilled } \\
\text { segment (\%) }\end{array}$ & $\begin{array}{c}\text { Mean slope } \\
(\%)\end{array}$ \\
\hline RS & 14.7 & 6.11 & 0.84 & 206 & 60.89 & 40.85 & 9.42 \\
SCF & 14.7 & 5.94 & 0.84 & 48 & 24.66 & 50.61 & 37.62 \\
CS & 14.7 & 6.13 & 0.84 & 79 & 45.80 & 9.66 & 35.41 \\
ST & 1.9 & 6.00 & 0.11 & 47 & 28.97 & 68.86 & 29.65 \\
\hline
\end{tabular}

RS: Road surface, SCF: Sidecast fill, RC: Road cut, ST: Skid trail

\section{Data}

The length, width and depth of rills on each specified road segment were measured by a measuring tape. The slope of rills and the road were measured by a clinometer. Intersecting rills were measured up to the point of junction with the main rill. As a means for an accurate estimation of the erosion on road segments, width and depth measurements were performed at three meter intervals. Measurements were conducted on a total of 427 rills at road surface, road cut, sidecast fill and skid trail sections.

The statistical evaluation of the relationship between slope and length of road segments, which are the effective factors on the amount of road-induced erosion, and erosion was carried out using ANOVA (one-way analysis of variance), Pearson correlation analysis, and RMSE (the root mean square error). ANOVA was used to make a comparison of rill volumes and road segments, Pearson was used for correlation analysis and evaluation of the relationship between the effective factors and roadinduced erosion, and RMSE was used to evaluate the efficiency of the estimation models for soil erosion. RMSE is defined with the following Equation 1 (Bhuyan et al., 2002).

$$
R M S E=\sqrt{\frac{\sum_{i=1}^{n}\left(o_{i}-P_{i}\right)^{2}}{n}}
$$

In Equation 1, $\mathrm{O}_{\mathrm{i}}$ and $\mathrm{P}_{\mathrm{i}}$ denotes the observed and estimated values, and $\mathrm{n}$ denotes the sum of each value pair. Smaller RMSE values indicate higher consistency between the estimated and the observed values.

\section{Results and discussion}

\section{Road segments and rill characteristics}

Significantly high ratio of rill were encountered on the skid trail and the road segments other than RC (Table 1). Ratio of rill depending on the road length were found as $40.85 \%, 50.61 \%$ and $68.86 \%$ respectively for RS, SCF and ST. The results show that, logging roads are subject to higher erosion than RS, and SCF despite being less frequently used and being subject to higher compaction. In general, the slope values of eroded road sections were found to be higher than the average values.

Although the determined erosion rates were higher for RS, erosion values per unit area $(\mathrm{km})$ were found to be close to each other for RS and ST. The underlying reason 
for RS's making the biggest contribution to road-induced sediment formation is its having the highest segment length, which results in the highest surface area. Formation of 227 rills on RSs (Table 2) supports this finding. Vehicle-induced disintegration of the road surface material also contributes to this situation. Despite the similar average widths of RS and ST at the sampling locations, the difference in the lengths of the two road segments affect rill formation and the resulting rill volume in favor of RS. A difference was also detected between RS and the other road segments after the ANOVA test $\left(\mathrm{p}<5.3110^{-7}\right)$. In terms of the average rill lengths, RS and ST took the first two places, which further indicated that these road segments produced the highest amount of sediment (Table 2). This is mainly attributable to the higher distances at which run-off accumulation and repetition occurs for the mentioned road segments. Among the rill characteristics such as slope, length and volume, the latter two have been found to be more effective on sediment yield. The rill slope for RS is statistically significantly lower than the other road segments $\left(\mathrm{p}<210^{-16}\right)$. High sediment yield despite low slope value can be ascribed to the lower erosion strength of the surface material for RS; and higher erosion strength for SCF, RC and ST which are impaired to a lesser degree.

Table 2. Rill characteristics for different road segments

\begin{tabular}{c|c|c|c|c|c|c|c}
\hline $\begin{array}{c}\text { Road } \\
\text { section }\end{array}$ & $\begin{array}{c}\text { Rill } \\
\text { count }\end{array}$ & $\begin{array}{c}\text { Total rill } \\
\text { volume }\left(\mathbf{m}^{\mathbf{3}}\right)\end{array}$ & $\begin{array}{c}\text { Soil loss per } \\
\mathbf{k m}\left(\mathbf{m}^{\mathbf{3}} \mathbf{k m}^{-\mathbf{1}}\right)\end{array}$ & $\begin{array}{c}\text { Maximum rill } \\
\text { volume }\left(\mathbf{m}^{\mathbf{3}}\right)\end{array}$ & $\begin{array}{c}\text { Average rill characteristics } \\
\text { Length } \\
(\mathbf{m})\end{array}$ & $\begin{array}{c}\text { Volume } \\
\left(\mathbf{m}^{\mathbf{3}}\right)\end{array}$ & $\begin{array}{c}\text { Rill slope } \\
(\mathbf{\%})\end{array}$ \\
\hline $\mathrm{RS}$ & 227 & 97.56 & 6.64 & 5.60 & $19.22 \mathrm{a}$ & $0.47 \mathrm{a}$ & $5.84 \mathrm{a}$ \\
$\mathrm{SCF}$ & 65 & 10.52 & 0.71 & 3.32 & $12.48 \mathrm{a}$ & $0.22 \mathrm{~b}$ & $44.81 \mathrm{~b}$ \\
$\mathrm{RC}$ & 85 & 3.20 & 0.22 & 0.17 & $4.42 \mathrm{~b}$ & $0.04 \mathrm{~b}$ & $35.68 \mathrm{~b}$ \\
$\mathrm{ST}$ & 50 & 11.53 & 6.11 & 1.68 & $19.95 \mathrm{c}$ & $0.24 \mathrm{~b}$ & $29.65 \mathrm{c}$ \\
\hline
\end{tabular}

RS: Road surface, SCF: Sidecast fill, RC: Road cut, ST: Skid trail

\section{The factors that affect rill erosion}

Unpaved forest roads exhibit the highest sediment yield values in all forestlands (Akay et al., 2008; Binkley and Brown, 1993; Mcclelland et al., 1999; Reid and Dunne, 1984). The sediment yield produced on the surface of the road is dependent on the traffic intensity, the surface type of the road, material characteristics, dimensions and the slope (Lang et al., 2018; Rhee et al., 2018; Erdem et al., 2018). Accordingly, the factors such as road, segment and rill lengths, rill volume, segment area and the slope of road segments were examined for determination of sediment yield from road segments and investigation of the relationships between the obtained data. These data are also used in several erosion models such as SEDMODL, FROSAM (The Forest Road Sediment Assessment Methodology), WARSEM, ROADMOD (Seutloali et al., 2015; Morgan and Nearing, 2016; Safari et al., 2016; Rose, 2017).

When the determined rill volumes were subjected to Pearson correlation test with the slope, segment length and segment area values, varying levels of significant relationships were found between the total rill volume and the stated variables for all road segments. The highest correlation among these variables was found between rill volume and segment length for all road segments (RS: $p<2.210^{-16}$ and $r=0.84$, SCF: $\mathrm{p}=1.76710^{-6}$ and $\mathrm{r}=0.68, \mathrm{RC}: \mathrm{p}=2.2210^{-15}$ and $\mathrm{r}=0.75, \mathrm{ST}: \mathrm{p}=1.29910^{-11}$ and $\mathrm{r}=0.80)($ Table 3$)$. 
Table 3. Relationship between rill volume and segment length, segment area variables

\begin{tabular}{c|c|c}
\hline $\begin{array}{c}\text { Road } \\
\text { section }\end{array}$ & Segment length & Segment area \\
\hline $\mathrm{RS}$ & $\mathrm{p}<2.210^{-16} ; \mathrm{r}=0.84 ; \mathrm{t}=22.593 ; \mathrm{df}=204$ & $\mathrm{p}<2.210^{-16} ; \mathrm{r}=0.66 ; \mathrm{t}=12.666 ; \mathrm{df}=204$ \\
$\mathrm{SCF}$ & $\mathrm{p}=1.7710^{-6} ; \mathrm{r}=0.63 ; \mathrm{t}=5.473 ; \mathrm{df}=46$ & $\mathrm{p}=3.0310^{-7} ; \mathrm{r}=0.66 ; \mathrm{t}=5.986 ; \mathrm{df}=46$ \\
$\mathrm{RC}$ & $\mathrm{p}=2.2210^{-5} ; \mathrm{r}=0.75 ; \mathrm{t}=9.892, \mathrm{df}=77$ & $\mathrm{p}=1.7810^{-15} ; \mathrm{r}=0.75 ; \mathrm{t}=9.954 ; \mathrm{df}=77$ \\
$\mathrm{ST}$ & $\mathrm{p}=1.3010^{-11} ; \mathrm{r}=0.80 ; \mathrm{t}=8.992 ; \mathrm{df}=45$ & $\mathrm{p}=7.2410^{-13} ; \mathrm{r}=0.83 ; \mathrm{t}=9.895 ; \mathrm{df}=45$ \\
\hline
\end{tabular}

RS: Road surface, SCF: Sidecast fill, RC: Road cut, ST: Skid trail

The equations obtained after a collective evaluation of the variables such as slope, segment length and segment area with stepwise regression analysis (forward-backward) and resulting $\mathrm{p}$ and $\mathrm{R}^{2}$ values are as follows (Eqs. 2-5):

For RS:

$$
\mathrm{E}=1.11 \mathrm{~L}+2.09 \mathrm{~S}-24.03 \quad\left(\mathrm{p}<0.001 ; \mathrm{R}^{2}=0.753\right)
$$

For SCF:

$$
E=0.13 S+0.25 L-8.45 \quad\left(p<0.001 ; R^{2}=0.433\right)
$$

For RC:

$$
\mathrm{E}=0.02 \mathrm{~S}+0.02 \mathrm{~L}+0.23 \quad\left(\mathrm{p}<0.001 ; \mathrm{R}^{2}=0.632\right)
$$

For ST:

$$
E=0.29 L+0.34 \quad\left(p<0.001 ; R^{2}=0.642\right)
$$

$\mathrm{P}$ values are lower than 0.001 in all equations. In the equations, $\mathrm{E}$ is rill volume, $\mathrm{S}$ is slope, and L is segment length. As inferred from the equations, the combined effect of the increase in segment length and the increase in slope results in increased erosion. Similar results were also reported by Qin et al. (2018), Zhang et al. (2017), and Navarro-Hevia (2016).

As the road widths within the study area are either identical or very close to each other, the effective factor for rill volume in the segment area is the segment length. Therefore, the Pearson coefficients obtained for each road segment were similar for segment length and segment area. Moreover, as shown in Table 3, segment length and segment area yield similar results for SCF, RC and ST, whereas a higher correlation is obtained with segment length for RS. Stepwise regression Equations 2, 3 and 4 obtained for each road segment show that, slope and segment length together yield higher correlation values. Therefore, the increase in segment area, which is in parallel to the increase in segment length, results in increased rill volume. Also, after a slope-based categorization of the road segments, the findings for erosion estimation increased significantly (Fig. 4). A wide scale of high slope values was observed for SCF, RC and ST, whereas the slope values of RS varied between $2-11 \%$ as per the standards for B- 
type side roads. As a result of the narrow range of the slope values and similar erosion amounts corresponding to the slopes lower than 5\%, the "RS $<5 \%$ " graph given in Figure 4 exhibits a steeper slope as compared to the other graphs. This result is also indicative of the geometric increase in erosion amounts that occur on the road surface with increasing slope.

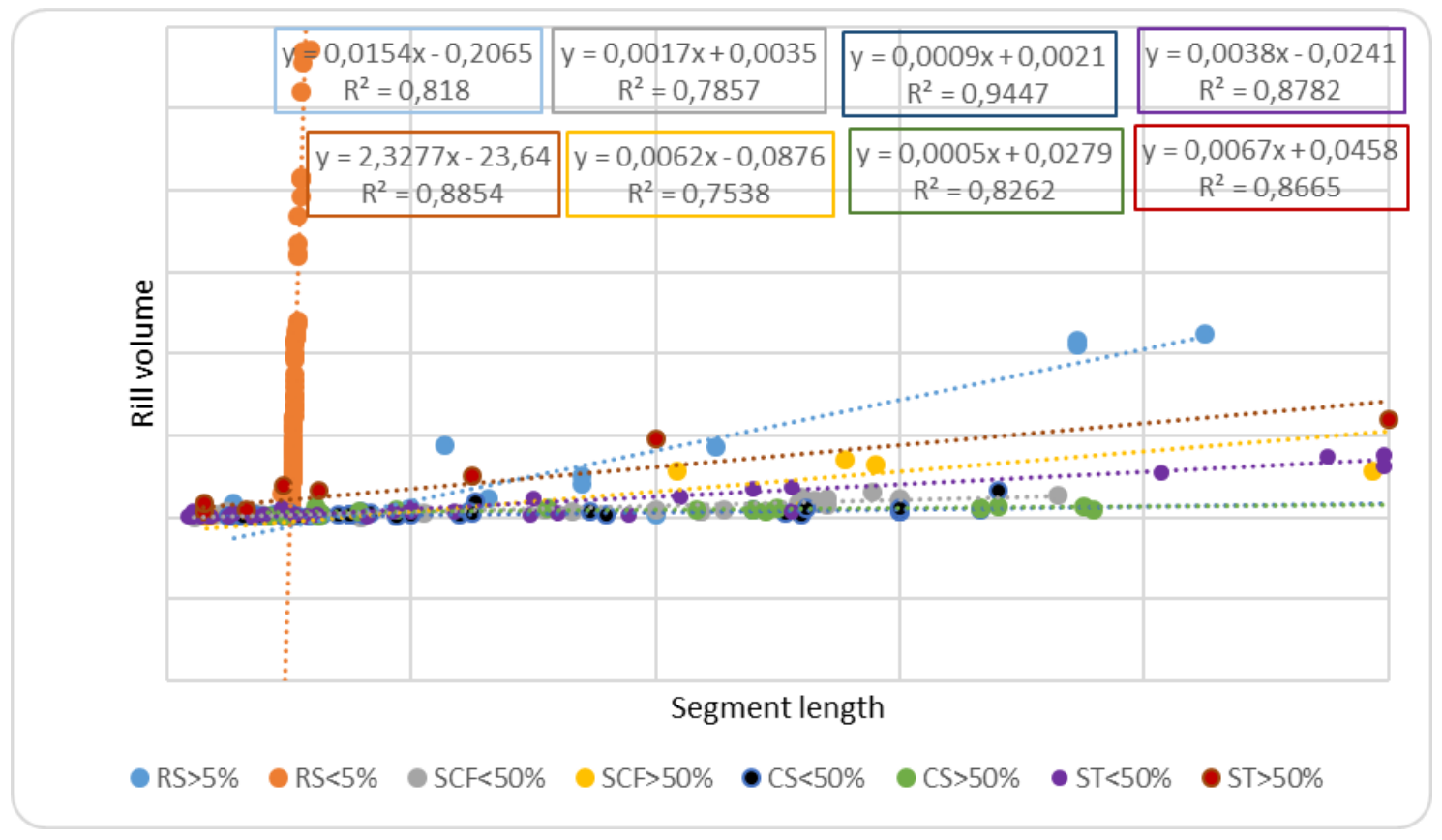

Figure 4. Rill volumes depending on segment lengths which are categorized by their slope

As also stated by Cao et al. (2014, 2015), rill volumes on short and steep road segments may be sometimes lower than those on low slope road segments. Accordingly, we also evaluated the rill volumes per unit segment area. According to the results of the correlation analysis between rill volumes per unit area and slope, the medium level correlation between slope and rill volume for RS and ST increased to a higher level (Table 4). As for SCF, the high level of correlation remained at a high level with a higher coefficient. On the contrary, the correlation level for RC with short and low slopes dropped to weak from medium, thus the effect of the slope factor on rill erosion is more evident for RS and ST. It is also revealed by the literature findings (Seutloali and Beckedahl, 2015; Anochie-Boateng et al., 2017; Safari et al., 2016; Thomaz and Ramos-Scharron, 2015; Yousefi et al., 2016) that, slope has a positive effect in the increase of rill erosion.

Table 4. Correlation of total and unit rill volumes for each road segment with slope

\begin{tabular}{c|c|c}
\hline Road section & Rill Volume $\left(\mathbf{m}^{\mathbf{3}}\right)$ & Unit Rill Volume $\left(\mathbf{m}^{\mathbf{3}} / \mathbf{m}^{\mathbf{2}}\right)$ \\
\hline $\mathrm{RS}$ & $\mathrm{p}<2.210^{-16} ; \mathrm{r}=0.55 ; \mathrm{t}=22.593 ; \mathrm{df}=204$ & $\mathrm{p}<2.2010^{-16} ; \mathrm{r}=0.81 ; \mathrm{t}=22.984 ; \mathrm{df}=204$ \\
$\mathrm{SCF}$ & $\mathrm{p}=3.6710^{-9} ; \mathrm{r}=0.73 ; \mathrm{t}=7.316 ; \mathrm{df}=46$ & $\mathrm{p}=1.3310^{-15} ; \mathrm{r}=0.77 ; \mathrm{t}=11.869 ; \mathrm{df}=46$ \\
$\mathrm{RC}$ & $\mathrm{p}=5.1210^{-8} ; \mathrm{r}=0.57 ; \mathrm{t}=6.039 ; \mathrm{df}=77$ & $\mathrm{p}=6.5610^{-5} ; \mathrm{r}=0.43 ; \mathrm{t}=4.222 ; \mathrm{df}=77$ \\
$\mathrm{ST}$ & $\mathrm{p}=9.6010^{-7} ; \mathrm{r}=0.64 ; \mathrm{t}=5.670 ; \mathrm{df}=45$ & $\mathrm{p}=1.7110^{-13} ; \mathrm{r}=0.84 ; \mathrm{t}=10.357 ; \mathrm{df}=45$ \\
\hline
\end{tabular}

RS: Road surface, SCF: Sidecast fill, RC: Road cut, ST: Skid trail 
In forestry, as the length of forest roads towards consumption centers increase, the length of inclined distances also increases. This in turn results in increased road-induced erosion risk and sediment yield. This situation is shown for each road segment in Figure 4 that gives the correlation between segment length and rill volume for each slope category. Table 5 gives the equations used in previous studies for estimation of erosion on unpaved forest roads. Variables such as $\mathrm{L}, \mathrm{S}, \mathrm{L}^{1 / 2}, \mathrm{~S}^{2}, \mathrm{LS}, \mathrm{LS}^{2}, \mathrm{~L}^{1 / 2} \mathrm{~S}^{2}$ are used in these equations, which indicate that, segment length and slope are the right variables for estimation of rill erosion. As also shown in Table 5, the regression equations involving $\mathrm{LS}$ and $\mathrm{LS}^{2}$ variables yielded the best results.

Table 5. Comparison of the models and statistical results of segment length and slope-based rill erosion estimation studies with the research data

\begin{tabular}{|c|c|c|c|c|}
\hline Model & $\mathbf{R}^{2}$ & Reference & Model & $\mathbf{R}^{2}$ \\
\hline$E=a L+b$ & 0.131 & Luce et al. (1999) & $\mathrm{E}=0.02 \mathrm{~L}+0.97$ & $0.052^{* * *}$ \\
\hline $\mathrm{E}=\mathrm{aS}-\mathrm{b}$ & $0.160^{*}$ & Cao et al. (2014) & $\mathrm{E}=0.11 \mathrm{~S}-0.38$ & $0.221^{* * * *}$ \\
\hline$E=a L^{1 / 2}-b$ & $0.790^{* *}$ & Cao et al. (2014) & $\mathrm{E}=0.64 \mathrm{~L}^{1 / 2}-1.23$ & $0.089^{* * *}$ \\
\hline $\mathrm{E}=\mathrm{a} \mathrm{S}^{2}+\mathrm{b}$ & $\begin{array}{l}0.494^{* *} \\
0.110^{*}\end{array}$ & $\begin{array}{l}\text { Luce et al. (1999) } \\
\text { Cao et al. (2014) }\end{array}$ & $\mathrm{E}=1.3810^{-3} \mathrm{~S}^{2}-0.13$ & $0.449^{* * *}$ \\
\hline $\mathrm{E}=\mathrm{aLS}+\mathrm{b}$ & $\begin{array}{l}0.580^{\text {**** }} \\
0.180^{* *}\end{array}$ & $\begin{array}{l}\text { Luce et al. (1999) } \\
\text { Madej (2001) }\end{array}$ & $E=7.6110^{-4} \mathrm{LS}+0,66$ & $0.244^{* * *}$ \\
\hline $\mathrm{E}=\mathrm{aLS} S^{2}+\mathrm{b}$ & $0.658^{* * *}$ & Luce et al. (1999) & $\mathrm{E}=9.5610^{-6} \mathrm{LS}^{2}+0.62$ & $0.498^{* * *}$ \\
\hline$E=a L^{1 / 2} S+b$ & $0.600^{* *}$ & Luce et al. (1999) & $\mathrm{E}=0.01 \mathrm{~L}^{1 / 2} \mathrm{~S}+0.13$ & $0.288^{* * *}$ \\
\hline$E=a L^{1 / 2} S^{2}+b$ & $0.629^{* *}$ & Luce et al. (1999) & $\mathrm{E}=1.2810^{-4} \mathrm{~L}^{1 / 2} \mathrm{~S}^{2}+0.41$ & $0.515^{* * * *}$ \\
\hline $\mathrm{E}=\mathrm{aL}+\mathrm{bS}+\mathrm{c}$ & $0.543^{* *}$ & Luce et al. (1999) & $\mathrm{E}=210^{-3} \mathrm{~L}+0.11 \mathrm{~S}-0.41$ & $0.221^{* * * *}$ \\
\hline $\mathrm{E}=\mathrm{aL}+\mathrm{bS}^{2}+\mathrm{c}$ & $0.577^{* * *}$ & Luce et al. (1999) & $\mathrm{E}=-3.7110^{-3} \mathrm{~L}+1.4010^{-3} \mathrm{~S}^{2}+0.21$ & $0.450^{* * * *}$ \\
\hline $\mathrm{E}=\mathrm{aL}+\mathrm{bLS} \mathrm{S}^{2}+\mathrm{c}$ & $0.662^{* * *}$ & Luce et al. (1999) & $\mathrm{E}=-2.4510^{-2} \mathrm{~L}+1.1310^{-5} \mathrm{LS}^{2}+1.17$ & $0.535^{* * *}$ \\
\hline $\mathrm{E}=\mathrm{aS}+\mathrm{bLS} S^{2}+\mathrm{c}$ & $0.658^{* * *}$ & Luce et al. (1999) & $E=-1.3510^{-2} S+1.0110^{-5} L^{2}+0.82$ & $0.499^{* * * *}$ \\
\hline $\mathrm{E}=\mathrm{a} \mathrm{S}^{2}+\mathrm{bLS} S^{2}+\mathrm{c}$ & $0.659^{* * *}$ & Luce et al. (1999) & $\mathrm{E}=5.0310^{-4} \mathrm{~S}^{2}+6.7110^{-6} \mathrm{LS}^{2}+0.37$ & $0.513^{* * *}$ \\
\hline $\mathrm{E}=\mathrm{aLS} S^{1.5}+\mathrm{b}$ & $0.840^{* * *}$ & Scharron (2010) & $E=9.3810^{-5} \mathrm{LS}^{1.5}+0.59$ & $0.378^{* * *}$ \\
\hline$E=-a L S^{0.13}+b$ & $0.830^{* *}$ & Scharron (2010) & $\mathrm{E}=0.02 \mathrm{LS}^{0.13}+0.93$ & $0.067^{* * * *}$ \\
\hline
\end{tabular}

a, b, c: Coefficients, L: Segment length, S: Slope

As indicated by the results, more accurate findings are obtained through use of the values determined for unit area. The relationships between the maximum and average rill volumes and slope for each road segment are shown in Figure 5. Maximum values for all road sections except RC shows high correlation. Erosion estimations were performed using shear stress values and stream power sediment transport capacity theory and the results are shown in Table 5. These values were obtained using the data received from all road segments. The resulting findings for each road segment are given in Table 6, and the RMSE results of these models are expected to provide higher accuracy in erosion estimations.

Road length, slope and drainage area are the factors that affect erosion. Eroded volume is directly associated with road length which affects soil erosion on road segments by the combined effect of slope. L (segment length) and S (slope) variables together yield better results than single independent variables. This is clearly verified by Equations 2, 3, 4 and 5, and the equations given in Table 6. The models shown in Table 6 involve the variables $\mathrm{L}, \mathrm{S}$ and $\mathrm{LS}^{2}$. These models yielded their best results for 
$\mathrm{RC}$, which features the shortest segment length, hence the lowest effectiveness. The models specified for RS and ST, which have similar segment lengths, exhibit similar mean error values.

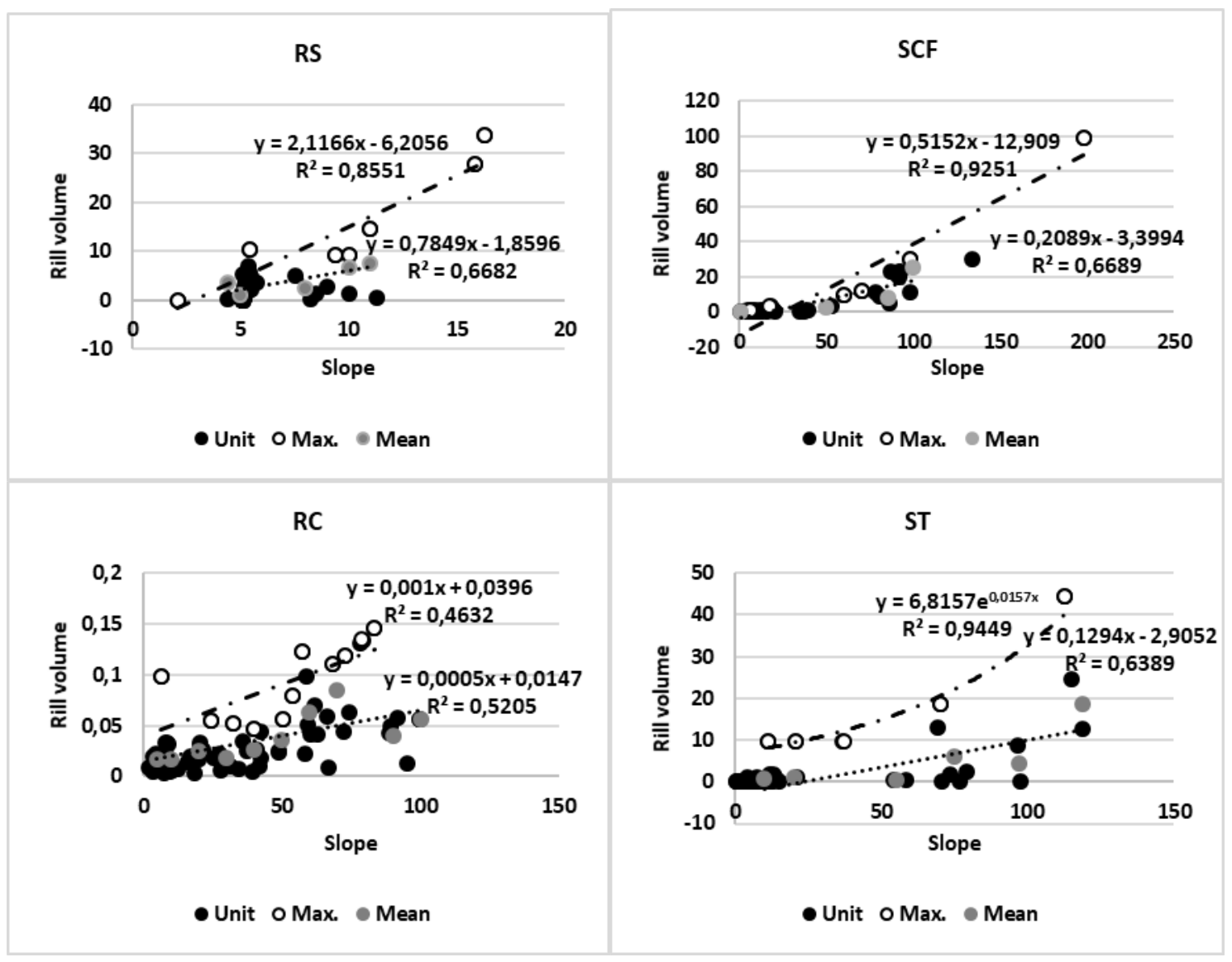

Figure 5. Maximum and average values of rill volumes as a function of slope

Table 6. Comparison of erosion models for road segments given in Table 5

\begin{tabular}{c|c|c}
\hline Road section & Model & RMSE \\
\hline RS & $\mathrm{E}=0.04 \mathrm{~L}+0.001 \mathrm{LS}^{2}+0.86$ & 0.16 \\
SCF & $\mathrm{E}=1.7110^{-3} \mathrm{~S}^{2}+4.2510^{-6} \mathrm{LS}^{2}-5.4810^{-2}$ & 0.32 \\
RC & $\mathrm{E}=8.3610^{-4} \mathrm{~S}-1.4410^{-8} \mathrm{LS}^{2}+8.6210^{-3}$ & 0.03 \\
ST & $\mathrm{E}=3.610^{-3} \mathrm{~L}+2.8610^{-7} \mathrm{LS}^{2}+4.8010^{-2}$ & 0.18 \\
TOTAL & $\mathrm{E}=-2.4510^{-2} \mathrm{~L}+1.1310^{-5} \mathrm{LS}^{2}+1.17$ & 1.45 \\
\hline
\end{tabular}

RS: Road surface, SCF: Sidecast fill, RC: Road cut, ST: Skid trail, L: Segment length, S: Slope

\section{Conclusion}

In this study, rill erosion characteristics of different segments of unpaved forest roads were investigated in Arıt and Hasankadı Forest sub-districts of Bartin Forestry Directorate. According to the research results, the highest soil erosion rate occurs on road surface, which is followed by sidecast fill and skid trail with similar values, and the lowest erosion rate is observed on skid trail Segment length and the slope of the road 
are the factors that affect erosion. As also reported in several other studies, more accurate statistical results are obtained via combined evaluation of segment length and slope. The findings of similar studies also indicate that better results can be obtained through inclusion of drainage area as a variable into the regression equations in estimation of rill erosion. On the other hand, drainage area slightly increases the accuracy of estimation equations particularly for unpaved forest roads. Inclined area had a negative effect on the observed road erosion especially on main roads. For such purposes, drainage area as a variable was excluded from the regression analysis as it is barely associated with the factors that affect road-induced erosion, although it resulted in 5, 10 and $8 \%$ increases in correlations for different types of forest roads. This brings about the necessity for evaluation of drainage areas' positive and negative contributions in addition to segment length and slope in future studies on determination of rill erosion. Also, similar studies should be performed on basins with more unpaved forest roads to widen the application extent of the findings obtained. In addition to the erosion rates on unpaved forest road segments, the sediment yield of other sections should also be determined for building road erosion models for basins.

\section{REFERENCES}

[1] Al-Awadhi, J. M. (2013): A case assessment of the mechanisms involved in human-induced land degradation in northeastern Kuwait. - Land Degradation \& Development 24(1): 2-11.

[2] Akay, A. E., Erdas, O., Reis, M., Yuksel, A. (2008): Estimating sediment yield from a forest road network by using a sediment prediction model and GIS techniques. - Building and Environment 43(5): 687-695.

[3] Anochie-Boateng, J. K., Sampson, L., Agyekum, P., Ampadu, K. O. (2017): Life-cycle cost comparison of alternative surfacing for steep slopes on low-volume roads in Ghana. - 8th Africa Transportation Technology Transfer Conference, Livingstone, Zambia, 8-10 May 2017.

[4] Bhuyan, S. J., Kalita, P. K., Janssen, K. A., Barnes, P. L. (2002): Soil loss predictions with three erosion simulation models. - Environmental Modelling \& Software 17(2): 135-144.

[5] Binkley, D., Brown, T. C. (1993): Forest practices as nonpoint sources of pollution in North America. - Journal of the American Water Resources Association 29(5): 729-740.

[6] Burroughs, E. R., Foltz, R. B., Robichaud, P. R. (1991): United states forest service research on sediment production from forest roads and timber harvest areas. Proceedings of the 10th World Forestry Congress, Paris 2: 187-193.

[7] Cao, L., Zhang, K., Liang, Y. (2014): Factors affecting rill erosion of unpaved loess roads in China. - Earth Surface Processes and Landforms 39(13): 1812-1821.

[8] Cao, L., Zhang, K., Dai, H., Liang, Y. (2015): Modeling interrill erosion on unpaved roads in the Loess Plateau of China. - Land Degradation \& Development 26(8): 825-832.

[9] Cao, L. X., Zhang, K. L., Dai, H. L., Guo, Z. L. (2011): Modeling soil detachment on unpaved road surfaces on the Loess Plateau. - Transactions of the ASABE 54(4): 13771384.

[10] Cochrane, T. A., Egli, M., Phillips, C., Acharya, G. (2007): Development of a forest road erosion calculation GIS tool for forest road planning and design. - International Congress on Modelling and Simulation: Land, Water \& Environmental Management: Integrating Systems for Sustainability. Christchurch. New-Zealand. p. 1273-1279. 
[11] Croke, J., Mockler, S. (2001): Gully initiation and road-to-stream linkage in a forested catchment, southeastern Australia. - Earth Surface Processes and Landforms 26(2): 205217.

[12] Croke, J., Hairsine, P., Fogarty, P. (1999): Sediment transport, redistribution and storage on logged forest hillslopes in south-eastern Australia. - Hydrological Processes 13(17): 2705-2720.

[13] Desprats, J. F., Raclot, D., Rousseau, M., Cerdan, O., Garcin, M., Le Bissonnais, Y., ... Monfort-Climent, D. (2013): Mapping linear erosion features using high and very high resolution satellite imagery. - Land Degradation \& Development 24(1): 22-32.

[14] Dougherty, W. J., Fleming, N. K., Cox, J. W., Chittleborough, D. J. (2004): Phosphorus transfer in surface runoff from intensive pasture systems at various scales. - Journal of Environmental Quality 33(6): 1973-1988.

[15] Douglas, I. (1993): Impact of roads and compacted ground on post-logging sediment yield in a small drainage basin, Sabah, Malaysia. - IAHS Publ. 216: 213-221.

[16] Dubé, K., Megahan, W. F., McCalmon, M. (2004): Washington Road Surface Erosion Model. - State of Washington Department of Natural Resources, Olympia.

[17] Dunne, T. (1979): Sediment yield and land use in tropical catchments. - Journal of Hydrology 42(3-4): 281-300.

[18] Eisenbies, M. H., Aust, W. M., Burger, J. A., Adams, M. B. (2007): Forest operations, extreme flooding events, and considerations for hydrologic modeling in the Appalachians-A review. - Forest Ecology and Management 242(2-3): 77-98.

[19] Elliot, W. J., Foltz, R. B., Robichaud, P. R. (2009): Recent Findings Related to Measuring and Modeling Forest Road Erosion. - In: Anderssen, R. S., Braddock, R. D., Newham, L. T. H. (eds.) Proc. of the 18th World IMACS/MODSIM Congress on International Congress on Modelling and Simulation. Cairns, Australia.

[20] Erdem, R., Enez, K., Demir, M., Sariyildiz, T. (2018): Slope effect on the sediment production of forest roads in Kastamonu of Turkey. - Fresenius Environmental Bulletin 27(4): 2019-2025.

[21] Fahey, B. D., Coker, R. J. (1989): Forest road erosion in the granite terrain of southwest Nelson, New Zealand. - Journal of Hydrology (New Zealand) 123-141.

[22] Foster, I. D., Rowntree, K. M., Boardman, J., Mighall, T. M. (2012): Changing sediment yield and sediment dynamics in the Karoo uplands, South Africa; post-European impacts. - Land Degradation \& Development 23(6): 508-522.

[23] Fransen, P. J., Phillips, C. J., Fahey, B. D. (2001): Forest road erosion in New Zealand: overview. - Earth Surface Processes and Landforms 26(2): 165-174.

[24] Froehlich, W. (1991): Sediment Production from Unmetalled Road Surfaces. - In: Peters, N. E., Walling, D. E. (eds.) Sediment and Stream Water Quality in a Changing Environment: Trends and Explanation. Proceedings of Vienna Symposium, August 1991, pp. 21-30. IAHS Press, Wallingford, UK.

[25] Froehlich, W., Walling, D. E. (1997): The role of unmetalled roads as a sediment source in the fluvial systems of the Polish Flysch Carpathians. - IAHS Publication 245: 159-168.

[26] Fu, B., Newham, L. T., Ramos-Scharron, C. E. (2010): A review of surface erosion and sediment delivery models for unsealed roads. - Environmental Modelling \& Software 25(1): 1-14.

[27] Grayson, R. B., Haydon, S. R., Jayasuriya, M. D. A., Finlayson, B. L. (1993): Water quality in mountain ash forests - separating the impacts of roads from those of logging operations. - Journal of Hydrology 150(2-4): 459-480.

[28] Gucinski H, Furniss, M. J., Ziemer, R. R., Brookes, M. H. (2001): Forest roads: A synthesis of scientific information. - General Technical Report PNW-GTR-509. USDA Forest Service: Portland, OR.

[29] Ketcheson, G. L., Megahan, W. F., King, J. G. (1999): "R1-R4” and "BOISED” sediment prediction model tests using forest roads in granitics. - Journal of the American Water Resources Association 35(1): 83-98. 
[30] Kumapley, N. K. (1987): Erosion of Unsurfaced Earth and Gravel Roads. - In: Proceedings of 9th Regional Conference for Africa on Soil Mechanics and Foundation Engineering, pp. 397-404.

[31] Lang, A. J., Aust, W. M., Bolding, M. C., McGuire, K. J., Schilling, E. B. (2018): Best Management Practices Influence Sediment Delivery from Road Stream Crossings to Mountain and Piedmont Streams. - Forest Science 64(6): 682-695.

[32] Leh, M., Bajwa, S., Chaubey, I. (2013): Impact of land use change on erosion risk: an integrated remote sensing, geographic information system and modeling methodology. Land Degradation \& Development 24(5): 409-421.

[33] Luce, C. H., Black, T. A. (1999): Sediment production from forest roads in western Oregon. - Water Resources Research 35(8): 2561-2570.

[34] Luce, C. H., Wemple, B. C. (2001): Introduction to special issue on hydrologic and geomorphic effects of forest roads. - Earth Surface Processes and Landforms 26(2): 111113.

[35] MacDonald, L. H., Sampson, R. W., Anderson, D. M. (2001): Runoff and road erosion at the plot and road segment scales, St John, US Virgin Islands. - Earth Surface Processes and Landforms: The Journal of the British Geomorphological Research Group 26(3): 251-272.

[36] Madej, M. A. (2001): Erosion and sediment delivery following removal of forest roads. Earth Surface Processes and Landforms: The Journal of the British Geomorphological Research Group 26(2): 175-190.

[37] Mcclelland, D., Foltz, R., Falter, C., Wilson, W., Cundy, T., Schuster, R., ... Heinemann, R. (1999): Relative effects on a low-volume road system of landslides resulting from episodic storms in northern Idaho. - Transportation Research Record: Journal of the Transportation Research Board (1652): 235-243.

[38] McGroddy, M., Lawrence, D., Schneider, L., Rogan, J., Zager, I., Schmook, B. (2013): Damage patterns after Hurricane Dean in the southern Yucatán: Has human activity resulted in more resilient forests? - Forest Ecology and Management 310: 812-820.

[39] Megahan, W. F. (1987): Effects of Forest Roads on Watershed Function in Mountainous Areas. - In: Balasubramaniam, A. S. et al. (eds). Environmental Geotechnics and Problematic Soils and Rocks. Balkema Publishing, Rotterdam, pp. 335-347.

[40] Merritt, W. S., Letcher, R. A., Jakeman, A. J. (2003): A review of erosion and sediment transport models. - Environmental Modelling \& Software 18(8-9): 761-799.

[41] Morgan, R. P. C., Nearing, M. (Eds.). (2016): Handbook of Erosion Modelling. - John Wiley \& Sons, Chichester, UK.

[42] Navarro-Hevia, J., Lima-Farias, T. R., de Araújo, J. C., Osorio-Peláez, C., Pando, V. (2016): Soil erosion in steep road cut slopes in Palencia (Spain). - Land Degradation \& Development 27(2): 190-199.

[43] Qin, W., Guo, Q., Cao, W., Yin, Z., Yan, Q., Shan, Z., Zheng, F. (2018): A new RUSLE slope length factor and its application to soil erosion assessment in a Loess Plateau watershed. - Soil and Tillage Research 182: 10-24.

[44] Posthumus, H., Deeks, L. K., Fenn, I., Rickson, R. J. (2011): Soil conservation in two English catchments: linking soil management with policies. - Land Degradation \& Development 22(1): 97-110.

[45] Ramos-Scharrón, C. E., MacDonald, L. H. (2005): Measurement and prediction of sediment production from unpaved roads, St John, US Virgin Islands. - Earth Surface Processes and Landforms 30(10): 1283-1304.

[46] Ramos-Scharrón, C. E., MacDonald, L. H. (2007): Measurement and prediction of natural and anthropogenic sediment sources, St. John, US Virgin Islands. - Catena 71(2): 250266.

[47] Scharrón, C. E. R. (2010): Sediment production from unpaved roads in a sub-tropical dry setting-Southwestern Puerto Rico. - Catena 82(3): 146-158. 
[48] Reid, L. M., Dunne, T. (1984): Sediment production from forest road surfaces. - Water Resources Research 20(11): 1753-1761.

[49] Rhee, H., Fridley, J., Page-Dumroese, D. (2018): Traffic-induced changes and processes in forest road aggregate particle-size distributions. - Forests 9(4): 181.

[50] Rose, C. W. (2017): Research Progress on Soil Erosion Processes and a Basis for Soil Conservation Practices. - In: Lal, R. (ed.) Soil Erosion Research Methods. Routledge, London, pp. pp. 159-180.

[51] Safari, A., Kavian, A., Parsakhoo, A., Saleh, I., Jordán, A. (2016): Impact of different parts of skid trails on runoff and soil erosion in the Hyrcanian forest (northern Iran). Geoderma 263: 161-167.

[52] Seutloali, K. E., Beckedahl, H. R. (2015): A review of road-related soil erosion: an assessment of causes, evaluation techniques and available control measures. - Earth Sciences Research Journal 19(1): 73-80.

[53] Sidle, R. C., Pearce, A. J., O'Loughlin, C. L. (1985): Hillslope Stability and Land Use. Water Resources Monograph Series No. 11. American Geophysical Union, Washington, DC.

[54] Tanimoto, S. (1999): U.S. Patent No. 5,893,898. - U.S. Patent and Trademark Office, Washington, DC.

[55] Thomaz, E. L., Ramos-Scharrón, C. E. (2015): Rill length and plot-scale effects on the hydrogeomorphologic response of gravelly roadbeds. - Earth Surface Processes and Landforms 40(15): 2041-2048.

[56] Tømmervik, H., Johansen, B., Høgda, K. A., Strann, K. B. (2012): High-resolution satellite imagery for detection of tracks and vegetation damage caused by all-terrain vehicles (ATVs) in Northern Norway. - Land Degradation \& Development 23(1): 43-52.

[57] Varol, T. (2015): Comparison of the models used in the calculation of surface erosion in unpaved forest roads. - Precise Forestry Symposium on Production, 4-6 June, IlgazKastamonu/Turkey, Proceedings Book, pp. 434-450.

[58] Varol, T. (2016): Runoff and soil erosion on unpaved forest road. - FETEC-2016, $1^{\text {st }}$ International Symposium of Forest Engineering and Technologies, 02-04 June, Bursa/Turkey, Proceedings Book, pp. 254-264.

[59] Varol, T., Ertuğrul, M. (2015): Climate change and Forest Fire Trend in the Aegean and Mediterranean Regions of Turkey. - Fresenius Environmental Bulletin 24(10B): 34363444.

[60] Xu, X. X., Ju, T. J., Zheng, S. Q. (2007): Field study on biological road erosion in loess hilly region. - Journal of Agro-Environment Science 26(3): 934-938.

[61] Xu, X. L., Liu, W., Kong, Y. P., Zhang, K. L., Yu, B., Chen, J. D. (2009): Runoff and water erosion on road side-slopes: Effects of rainfall characteristics and slope length. Transportation Research Part D: Transport and Environment 14(7): 497-501.

[62] Yousefi, S., Moradi, H., Boll, J., Schönbrodt-Stitt, S. (2016): Effects of road construction on soil degradation and nutrient transport in Caspian Hyrcanian mixed forests. Geoderma 284: 103-112.

[63] Zhang, X. C., Nearing, M. A., Garbrecht, J. D. (2017): Gaining insights into interrill erosion processes using rare earth element tracers. - Geoderma 299: 63-72.

[64] Ziegler, A. D., Sutherland, R. A., Giambelluca, T. W. (2000): Partitioning total erosion on unpaved roads into splash and hydraulic components: The roles of interstorm surface preparation and dynamic erodibility. - Water Resources Research 36(9): 2787-2791. 